\title{
EFFECTS OF CARBOHYDRATE AND ENDOGENOUS HORMONE CONTENT ON MORPHOLOGICAL STRUCTURE OF HETEROMORPHIC LEAVES OF POPULUS PRUINOSA SCHRENK.
}

\author{
LI, X. $.^{1,2,3}-$ HAN, X. L. ${ }^{1,2,3}-$ ZHAI, J. T. ${ }^{1,2,3}-$ ZHANG, S. H. ${ }^{1,2,3}-$ LI, Z. J. ${ }^{1,2,3 *}$ \\ ${ }^{1}$ Key Laboratory of Protection and Utilization of Biological Resources in Tarim Basin Xinjiang \\ Production and Construction Corps, Alar, Xinjiang 843300, China \\ ${ }^{2}$ Desert Poplar Research Center of Tarim University, Alar, Xinjiang 843300, China \\ ${ }^{3}$ College of Life Science, Tarim University, Alar, Xinjiang 843300, China \\ ${ }^{*}$ Corresponding author \\ e-mail: lizhijun0202@126.com; phone: +86-997-468-1202
}

(Received $28^{\text {th }} \mathrm{Jul} 2021$; accepted $20^{\text {th }}$ Sep 2021)

\begin{abstract}
Populus pruinosa Schrenk. (P. pruinose) has the biological characteristic of heteromorphic leaves, which is related to growth and adaptation to extreme arid environments. The present study aimed to clarify whether carbohydrate and endogenous hormone content had an effect on the morphological structure of $P$. pruinose heteromorphic leaves on canopy height during ontogenesis. Petiole length, upper epidermal cell length, upper epidermal cell number, lower epidermal cell length, palisade tissue cell number, palisade tissue thickness, palisade tissue cell width and palisade tissue/spongy tissue ratio were very significantly positively correlated with diameter at breast height (DBH) and canopy height. Spongy tissue thickness is significantly negatively correlated with diameter at breast height and canopy height, with advancements in the developmental stage and increase in canopy height, the heterophil xerophytic structure is more and more obvious. Zeatin-riboside content and zeatin-riboside/abscisic acid ratio positively correlated with diameter at breast height, while gibberellin/abscisic acid ratio negatively correlated with canopy height. Soluble sugar and soluble protein contents significantly positively correlated with diameter at breast height and canopy height, starch contents significantly negatively correlated with diameter at breast height and canopy height. Regression analysis showed that soluble sugar content had positive effects on petiole length, leaf width, leaf area, leaf circumference, leaf thickness, upper epidermal cell length, lower epidermal cell number, palisade tissue thickness and spongy tissue thickness. The soluble protein content had a positive effect on leaf index and palisade tissue/spongy tissue ratio, starch content had a positive effect on upper epidermal cell width and palisade tissue thickness. It was concluded that the endogenous hormone and carbohydrate content could enhance the xerophytic structure of heteromorphic leaves during ontogenesis.
\end{abstract}

Keywords: heteromorphic leaf, morphological anatomy, physiological characteristics, developmental stage, canopy height

Abbreviations. $\mathrm{LL}=$ Leaf length; $\mathrm{LW}=$ Leaf width; $\mathrm{LI}=$ leaf index; $\mathrm{LA}=$ leaf area; $\mathrm{LT}=$ leaf thickness; LC = leaf circumference; PL = petiole length; UECN = upper epidermal cell number; $\mathrm{LECN}=$ lower epidermal cell number; UECL $=$ upper epidermal cell length; LECL $=$ lower epidermal cell length; UECW = upper epidermal cell width; LECW = lower epidermal cell width; PN = palisade tissue cell number; PTT = palisade tissue thickness; $\mathrm{PTCL}=$ palisade tissue cell length; $\mathrm{PTCW}=$ palisade tissue cell width; STT = spongy tissue thickness; PSR = palisade tissue/spongy tissue ratio; SS = soluble sugar; $\mathrm{S}=$ starch; $\mathrm{SP}=$ soluble protein; $\mathrm{IAA}=$ indole acetic acid; $\mathrm{ZR}=$ zeatin-riboside; $\mathrm{GA}_{3}=$ gibberellin; $\mathrm{ABA}=$ abscisic acid; $\mathrm{CH}=$ canopy height DBH $=$ diameter at breast height 


\section{Introduction}

The heteromorphic foliage of plants refers to the various shapes of leaves at different growth stages or changes in environmental conditions, which reflects the greater plasticity and variability of leaves (Bai, 2003). Heteromorphic leaves play an important role in the adaptation of plants to environmental changes (Winn, 1999; Wells and Pigliucci, 2000), changes in leaf morphology of aquatic plants, for example, promote gas exchange under underwater conditions (Kuwabara and Nagata, 2002; Mommer and Visser, 2005). Leaf morphology and physiological function show considerable plasticity within the canopy, and in very tall trees a distinct vertical gradient is usually shown for various leaf traits (Cai and Song, 2001; Burgess et al., 2007). Kenzo et al. (2015) showed that there was a significant linear relationship between leaf morphology and biochemical characteristics and tree height. With the increase of tree height, the leaf structure of Parashorea chinensis showed more obvious xerophytic characteristics (He et al., 2008). In addition, some studies have found that the morphology, structure and physiological characteristics of the heteromorphic leaves of Populus euphratia Oliv. are more obvious with the increase of ontogenetic stage and tree height (Zhai et al., 2020). Studies have pointed out that plant hormones such as abscisic acid and gibberellin are closely related to the regulation of profiled leaves (Nakayama et al., 2017; Li et al., 2020), Abscisic acid (ABA) is mainly involved in the establishment and maintenance of morphological characteristics of heterophyllous plants (Wanke, 2011). Nakayama et al. (2014) showed that the difference of gibberellin content in leaf primordium also determined the leaf shape changes of plants, and the content and distribution of auxins (IAA) regulated the leaf shape changes of Arabidopsis thaliana, Cardamine hirsuta and other plants (Barkoulas et al., 2008; Ben-gera et al., 2012). Many studies have shown that starch, soluble sugar and soluble protein are involved in the growth and development of plants, and these soluble substances can maintain cell turgor and protect the integrity of cell membrane when plants are stressed by drought, salt and alkali and other environmental conditions (Kuang et al., 2017; Liu et al., 2017; Liu et al., 2020). A few studies on herbaceous plants suggest that starch, or the ratio of soluble sugar to starch, is a major integrator of plant growth regulation (Selbig et al., 2009; Purdy et al., 2015).

$P$. pruinosa is an important tree species in arid desert areas with biological characteristics of heteromorphic leaves. It has three different leaf shapes: long oval, round, and broad oval (Wei, 1990). The long elliptic leaves, round leaves, and broad ovoid leaves on the crown of $P$. pruinosa appear regularly in different stages of individual development (Liu et al., 2016), and with the increase of ontogenetic stages, the heteromorphic leaves of $P$. pruinosa show more obvious xerophytic structural characteristics (Zhai et al., 2019). At present, the research on P. pruinosa in the world focuses on stress-resistant physiology (Zhang et al., 2014; Wang et al., 2017; Li, 2020), However, the relationship between the morphological and structural changes of P. pruinosa heteromorphic leaves and the endogenous hormones and carbohydrate in leaves has not been reported, which is of great significance to reveal the physiological regulation mechanism of the enhanced drought-resistant structure of $P$. pruinosa heteromorphic leaves.

In this study, $P$. pruinosa growing on the same site at different stages of development was selected as the research object. Through studying the change rules and their relationships of morphological structure, carbohydrate content, endogenous hormone content and their ratio of heteromorphous leaves of $P$. pruinosa at different stages of 
development and vertical spatial changes of tree crown, the study aim to clarify the role of endogenous hormones and carbohydrate content in the morphological and structural changes of $P$. pruinosa heteromorphic leaves, and to lay a foundation for revealing the regulatory mechanism of morphological and structural changes of heteromorphic leaves at molecular level.

\section{Materials and Methods}

\section{Study site}

The study area is located in P. pruinosa forest in the northwest margin of Tarim Basin, Xinjiang, China ( $81^{\circ} 17^{\prime} 56.52^{\prime \prime} \mathrm{E}, 40^{\circ} 32^{\prime} 36.90^{\prime \prime} \mathrm{N}, 980 \mathrm{~m}$ above sea level). The study area has a hot and dry climate, with an average annual rainfall of about $50 \mathrm{~mm}$, an average annual temperature of $10.8{ }^{\circ} \mathrm{C}$, a potential evaporation of $1900 \mathrm{~mm}$ and an average annual sunshine duration of $2900 \mathrm{~h}$. It is a typical temperate desert climate. In the study area, the artificial $P$. pruinosa forest covers an area of $180.6 \mathrm{hm}^{2}$, and there are 293 P. pruinosa individuals at different development stages (different tree ages) in the forest. The accompanying species in the study area were Tamarix chinensis Lour., Glycyrrhiza uralensis Fisch., Phragmites australis (Cav.) trin.ex Steud, and Aeluropus pungens (M. Bieb.) C. Koch.

\section{Experimental design and sampling}

$P$. pruinosa with different diameters represented different developmental stages. Using the diameter at breast height (DBH) and $2 \mathrm{~cm}$ as class distance, the 293 $P$. pruinosa trees in the study area were divided into 9 diameter steps $(2,4,6,8,10,12$, 14,16 and 18), representing 9 developmental stages of $P$. pruinosa (Table 1). Three sample plants were selected in each diameter class. During the leaf maturity period, the sampling canopy height $(\mathrm{CH})$ was divided into 5 equal parts (total stations (GTS-2002, TOPCON) to measure the tree heights and under branch heights of trees in the different diameter classes from base to top was defined as 1 to 5 layers). At each sampling layer, three one-year-old branches were collected from each of the four directions (east, south, west, and north). Sixty branches were collected from each sampling tree. A total of 60 leaves per sampling were used to measure the leaf morphological, anatomical, and physiological characteristics. The leaves used for the physiological characteristics were immediately stored in liquid nitrogen after collection.

Table 1. Basic information of P. pruinosa

\begin{tabular}{c|c|c|c|c|c|c|c|c|c}
\hline Diameter classes & $\mathbf{2}$ & $\mathbf{4}$ & $\mathbf{6}$ & $\mathbf{8}$ & $\mathbf{1 0}$ & $\mathbf{1 2}$ & $\mathbf{1 4}$ & $\mathbf{1 6}$ & $\mathbf{1 8}$ \\
\hline Breast diameter range $(\mathrm{cm})$ & $0-2$ & $2-4$ & $4-6$ & $6-8$ & $8-10$ & $10-12$ & $12-14$ & $14-16$ & $16-18$ \\
Number of plants & 6 & 15 & 36 & 44 & 40 & 58 & 40 & 37 & 17 \\
Number of samples & 9 & 31 & 23 & 21 & 20 & 19 & 11 & 4 & 3 \\
Mean breast diameter (cm) & 2.2 & 4.1 & 6.1 & 8.2 & 10.5 & 11.8 & 13.9 & 15.8 & 17.8 \\
Average tree height (m) & 4.4 & 4.6 & 4.9 & 5.4 & 5.7 & 6.3 & 7.5 & 7.5 & 7.4 \\
Average crown height (m) & 4.4 & 5.7 & 7.1 & 8.5 & 10.7 & 11.6 & 12.2 & 12.7 & 13 \\
Average tree age (year) & 4.4 & 5.7 & 7.1 & 8.5 & 9.7 & 10.7 & 11.6 & 12.2 & 12.7 \\
\hline
\end{tabular}




\section{Leaf morphological and anatomical structure index determination}

The leaves at the third node from the base of the current branch were selected as the sample leaves, leaf length (LL), leaf width (LW), leaf area (LA), leaf circumference (LC), leaf thickness (LT) and petiole length (PL) were measured using a scanner (MRS9600TFU2) and LA-S plant image analysis software. The leaf shape index (LI) was calculated according to the ratio of leaf length to width.

The sample leaf was crosscut from the widest part and fixed with formalin-acetic acid-alcohol (FAA) solution. We used the paraffin section method to make tissue sections, the thickness of the sections was $8 \mu \mathrm{m}$, and the sections were stained with double saffron and solid green, and the sections were sealed with neutral resin. The upper epidermal cell number (UECN), lower epidermal cell number (LECN), upper epidermal cell length (UECL), lower epidermal cell length (LECL), upper epidermal cell width (UECW), lower epidermal cell width (LECW), palisade tissue thickness (PTT), palisade tissue cell number (PN), palisade tissue cell length (PTCL), palisade tissue cell width (PTCW) and spongy tissue thickness (STT) were measured under a Leica microscope (Leica DM4 B, Wetzlar, Germany). The palisade tissue/spongy tissue ratio (PSR) was calculated. Each blade has 5 fields of observation and 20 values of observation in each field. The average value of blade structure parameters in 5 fields of observation is taken as the parameter value of each blade structure.

\section{Leaf physiological and biochemical index determination}

The mixed sample of the leaves at the third node of the current branch in the same canopy of the sample plant was taken as the test sample, the soluble sugar content (SS) was determined by anthrone-sulfuric acid method, the starch content (S) was determined by anthrone-colorimetric method, and the soluble protein content (SP) was determined by Coomassie bright blue G-250 method (Gao, 2006).

\section{Leaf hormone content determination}

Stem tips of current shoots in the same canopy on the sample plant were mixed as test samples. Test samples were accurately weighed to $200 \mathrm{mg}$, and the contents of indole acetic acid (IAA), zeatin-riboside (ZR), gibberellin $\left(\mathrm{GA}_{3}\right)$ and abscisic acid (ABA) were determined by enzyme linked immunosorbent assay (ELISA) (Duan et al., 2009; Li et al., 2019).

\section{Data processing method}

A one-way ANOVA was used to compare the differences in the morphological structure and physiological characteristics of heteromorphic leaves. In SPSS 23.0, Duncan's new multiple range method was used for data analysis of variance. The significance of differences was determined at $\mathrm{a}=0.05$. Pearson correlation coefficient was used to test the correlation between each index, and stepwise regression analysis was conducted. 


\section{Results}

\section{Changes of morphological characteristics and structure of heteromorphic leaves with developmental stage and canopy height}

Leaf index of heteromorphic leaves decreased with the increase of diameter class (Figure 1A,C), while leaf width, leaf area, leaf circumference, leaf thickness and petiole length increased with the increase of diameter class and canopy height (Figure $1 B, D, E, F, G$ ), and the changes of leaf index, leaf area and leaf thickness were more obvious.

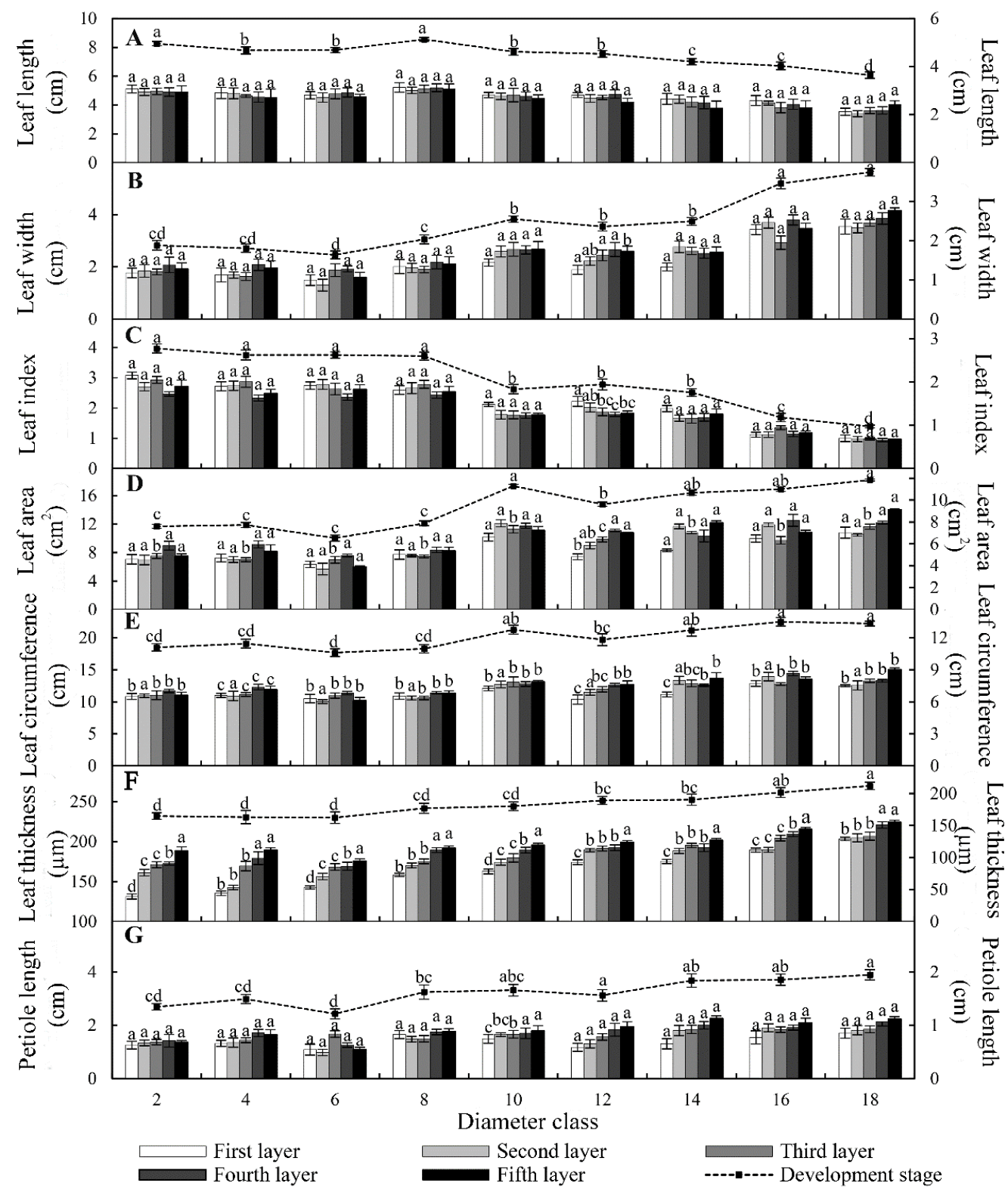

Figure 1. Variation of heteromorphic leaf morphology with developmental stages and canopy height of $P$. pruinose. (A) leaf length, (B) leaf width, (C) leaf index, (D) leaf area, (E)Leaf circumference, $(F)$ leaf thickness, $(G)$ petiole length. Lowercase letters indicated significant differences, the same letters indicated not significant $(P>0.05)$, and different letters indicated significant differences $(P<0.05)$ 
The upper and lower epidermal cell number of leaves increased with the increase of diameter class and canopy height (Figure $S 1 E, F$ ), while the upper and lower epidermal cell number increased more obviously with the increase of diameter class from 2 to 10 . In addition, the upper and lower epidermal cell length increased slowly with the increase of diameter class and canopy height, while the upper and lower epidermal cell width had no significant difference with the increase of diameter class and canopy height. The palisade tissue cell number, palisade tissue thickness and palisade tissue/spongy tissue ratio of leaves increased with the increase of diameter class and canopy height (Figure $S 2 A, D, F$ ), the spongy tissue thickness decreased with the increase of diameter class (Figure $S 2 E$ ), and the palisade tissue cell length increased with the increase of canopy height (Figure $S 2 B$ ). There were significant differences in the palisade tissue cell width between 2 and 4 diameter class.

Correlation analysis showed that (Table S1), petiole length, upper epidermal cell length, lower epidermal cell number, upper epidermal cell length, palisade tissue cell number, palisade tissue thickness, palisade tissue cell width and palisade tissue/spongy tissue ratio with DBH and canopy height was very significantly positively correlated, spongy tissue thickness with DBH and canopy height showed a significantly negative correlation. These results indicated that the morphological and structural changes of P. pruinosa heteromorphic leaves were closely related to the increase of diameter class and canopy height, and the xerophytic structural characteristics of heteromorphic leaves became more and more obvious with the increase of development stages and canopy height.

\section{Changes of endogenous hormone content and their ratios in heteromorphic leaves with developmental stages and canopy height}

We studied that the $\mathrm{GA}_{3}$ content, IAA/ABA, GA $3 / \mathrm{ABA}, \mathrm{ZR} / \mathrm{ABA}, \mathrm{GA}_{3} / \mathrm{IAA}$ ratio of heteromorphic leaves in the 4 diameter were significantly lower than those in other diameters (Figure 2 and Figure $S 3 A, B, C, D$ ), while $\mathrm{ZR} / \mathrm{GA}_{3}$ ratio was significantly higher than those of other diameter classes (Figure $S 3 F$ ). The ratios of IAA/ABA, $\mathrm{GA}_{3} / \mathrm{ABA}$ and $\mathrm{ZR} / \mathrm{ABA}$ in 4-12 diameter classes increased, while in 12-16 diameter classes decreased. In addition, the contents of $\mathrm{GA}_{3}$, IAA and $\mathrm{ZR}$ in the 16 diameter special-shaped leaves were significantly higher than those in other diameter classes (Figure $2 A, B, D$ ), while the contents of ABA and IAA in the 18 diameter special-shaped leaves were lower than those in other diameter classes (Figure 2B,C).

From the vertical space of tree crown, the content of $\mathrm{GA}_{3}$ in leaves basically decreased with the increase of canopy height at diameter classes 2, 12 and 14, but basically increased with the increase of $\mathrm{CH}$ at diameter classes 4 to 10,16 and 18 (Figure $2 A$ ). The ratios of $\mathrm{ZR} / \mathrm{GA}_{3}$ and $\mathrm{ZR} / \mathrm{IAA}$ of leaves basically increased with the increase of canopy height (Figure $S 3 E, F$ ), and there were significant differences between the first layer and the fifth layer. The content of IAA in leaves basically decreased with the increase of canopy height (Figure 2B), and the content of ZR in leaves basically increased with the increase of diameter classes, but the difference between tree crown levels was not significant (Figure 2D). The content of ABA in leaf of diameter classes 2, 6 and 8 showed a decreasing trend with the increase of $\mathrm{CH}$, but the content of ABA in diameter classes 4 and 10 to 18 basically showed an increasing trend with the increase of canopy height (Figure 2C). The IAA/ABA ratio of leaves decreased with canopy height from 12 to 18 diameter classes, and the 3rd layer of individual canopies from 6 and 18 diameter classes had significant differences with 
other canopies (Figure S3A). The ratios of $\mathrm{GA}_{3} / \mathrm{ABA}$ and $\mathrm{ZR} / \mathrm{ABA}$ in leaves were the highest in the third layer of the 6th diameter step, and there were significant differences with those in other canopy layers (Figure $S 3 B, C$ ).

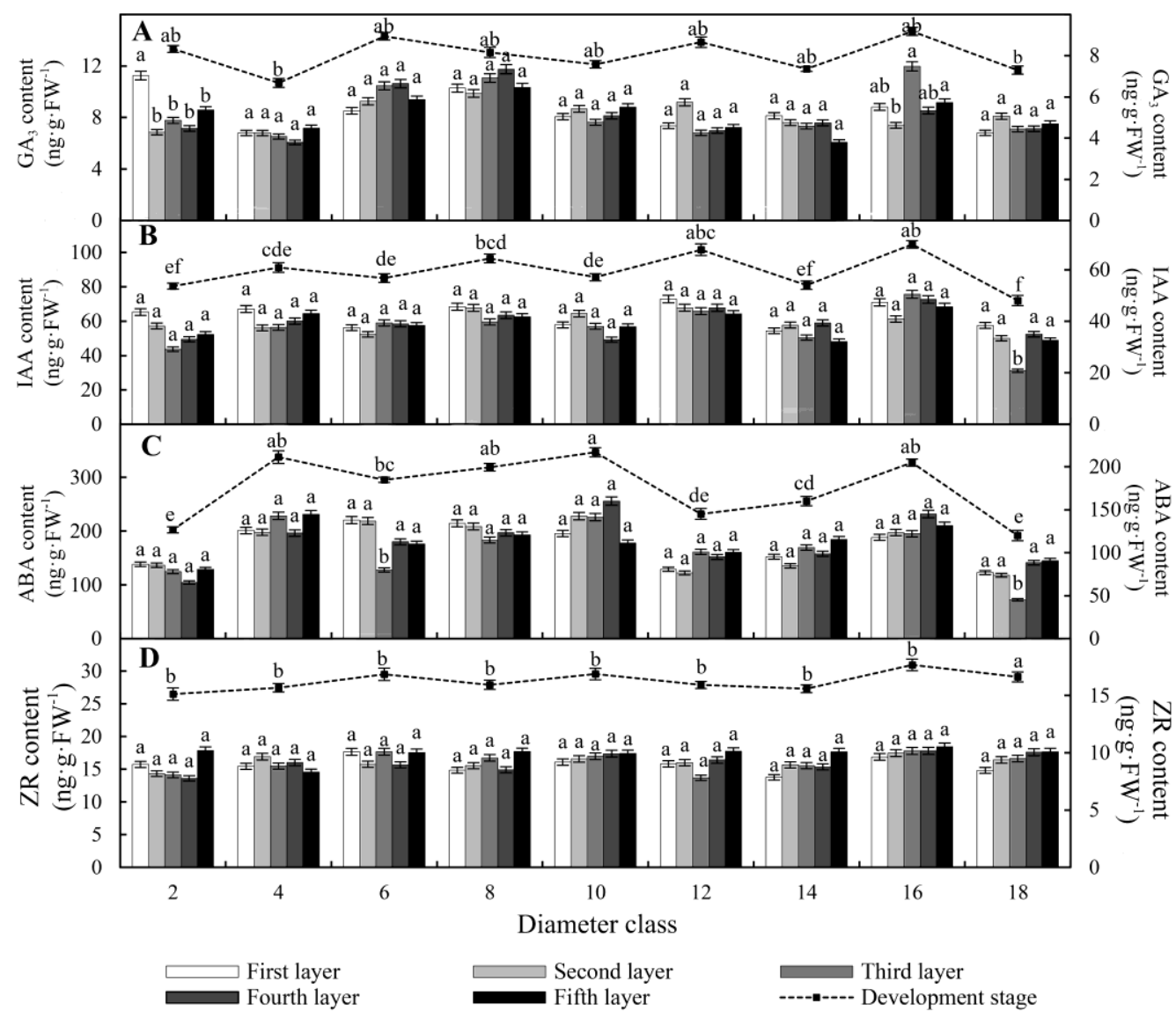

Figure 2. Changes of endogenous hormone content in heteromorphic leaves with developmental stages and canopy height. (A) leaf $G_{3}$ content, (B) leaf IAA content, (C) leaf ABA content, (D) leaf $Z R$ content. Lowercase letters indicated significant differences, the same letters indicated not significant $(P>0.05)$, and different letters indicated significant differences $(P<0.05)$

Correlation analysis showed that (Table S2), ZR content and ZR/ABA ratio positively correlated with $\mathrm{DBH}$, while $\mathrm{GA}_{3} / \mathrm{ABA}$ ratio negatively correlated with canopy height, it shows that they are closely related to the Ontogenetic stage and canopy height where the heteromorphic leaves are located.

\section{Changes of carbohydrate content in heteromorphic leaves with developmental stages and canopy height}

It was found that the contents of SS and SP in leaves increased with the increase of diameter classes and canopy height (Figure 3A,C), while the content of starch in leaves decreased with the increase of diameter classes, but increased with the increase of canopy height (Figure 3B). In 2 - 6 diameter classes leaf soluble sugar, soluble protein, and starch content in the canopy layers between there was no significant change, but in 
8 to 18 diameter classes there was a significant difference between the canopy height in each diameter class.

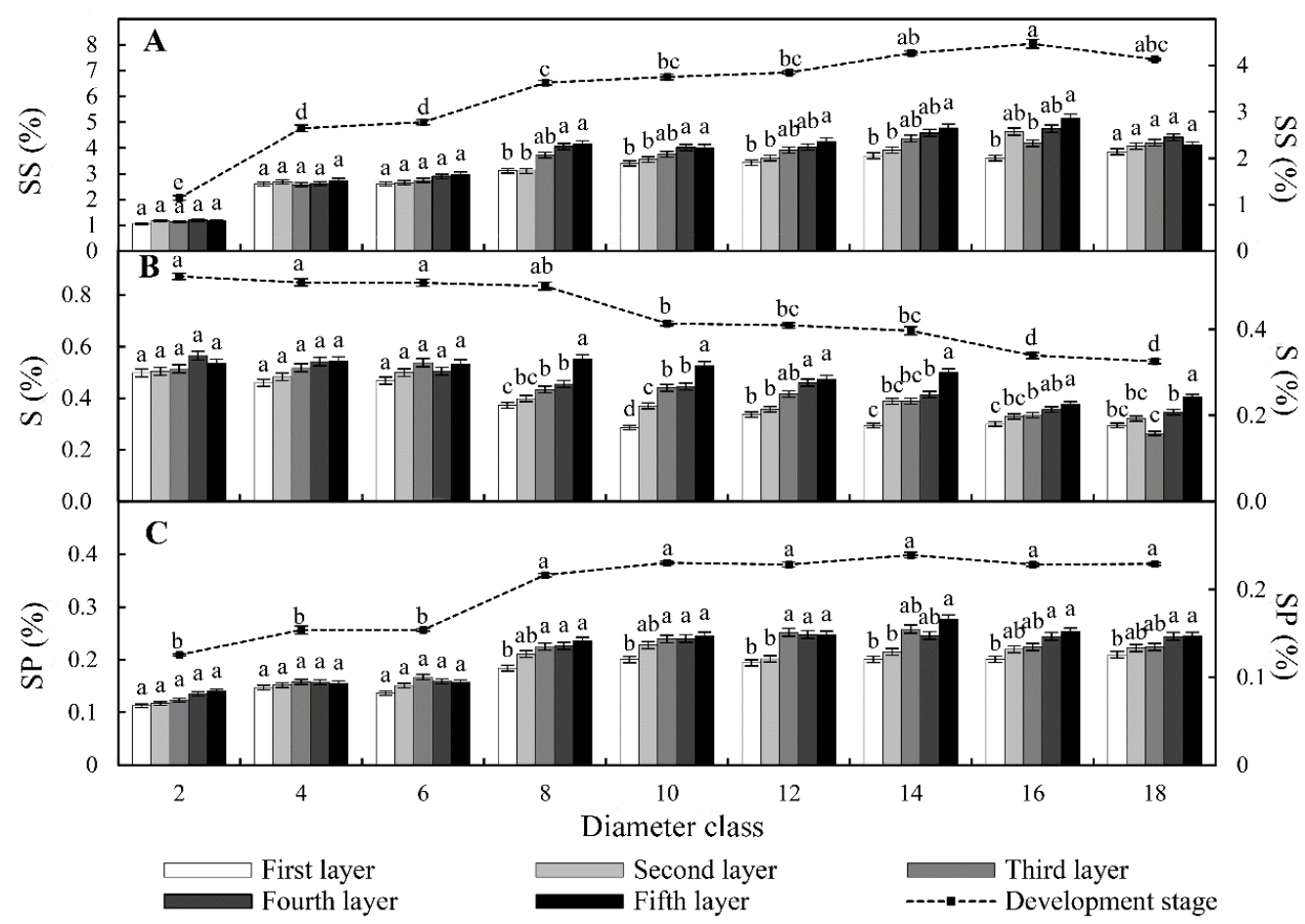

Figure 3. Changes of soluble sugar, starch and soluble protein contents in heteromorphic leaves with developmental stages and canopy height. (A) leaf soluble sugar content (SS), (B) leaf starch content $(S),(C)$ leaf soluble protein $(S P)$. Lowercase letters indicated significant differences, the same letters indicated not significant $(P>0.05)$, and different letters indicated significant differences $(P<0.05)$

Correlation analysis showed that the soluble sugar and soluble protein contents significantly positively correlated with $\mathrm{DBH}$ and canopy height, starch contents significantly negatively correlated with DBH and canopy height (Table S2). These results indicated that the changes of the contents of soluble sugar, soluble protein and starch in heteromorphic leaves were closely related to the ontogenetic stage and canopy height.

\section{Relationship between content and ratio of endogenous hormones in leaves and morphological structure of heteromorphic leaves}

Correlation analysis was conducted on the contents and ratios of endogenous hormones and morphological structure of four kinds of $P$. pruinosa heteromorphic leaves (Table 2), indicating that the content of $\mathrm{GA}_{3}$ and the ratio of ZR/IAA in P. pruinosa heteromorphic leaves significantly positively or negatively correlated with the lower epidermal cell width and lower epidermal cell length. The IAA content and IAA/ABA ratio significantly positively correlated with the palisade tissue cell length. ZR content and ZR/ABA ratio significantly positively correlated with Leaf width, leaf circumference, leaf area, leaf thickness, petiole length, upper epidermal cell length, palisade tissue thickness and palisade tissue/spongy tissue ratio, but negatively 
correlated with leaf length and leaf index. ABA content significantly positively correlated with the Leaf length, but negatively correlated with the upper epidermal cell length. The $\mathrm{GA}_{3} / \mathrm{ABA}$ ratio significantly positively correlated with leaf index, and significantly or negatively correlated with Leaf width, leaf area, leaf circumference, leaf thickness, petiole length, palisade tissue thickness, palisade tissue cell width and palisade tissue/spongy tissue ratio. The ratio of $\mathrm{GA}_{3} / \mathrm{IAA}$ significantly negatively correlated with the upper epidermal cell number, lower epidermal cell width and lower epidermal cell number, and positively correlated with the spongy tissue, while the ratio of $\mathrm{ZR} / \mathrm{GA}_{3}$ negatively correlated with the leaf area, leaf thickness, leaf length and petiole length. The results indicated that the changes of morphological structure of heteromorphic leaves of $P$. pruinosa were closely related to the changes of contents and ratios of these 4 endogenous hormones.

Table 2. The morphological and structural parameters of heteromorphic leaves correlated with Pearson's endogenous hormone content and ratio

\begin{tabular}{c|c|c|c|c|c|c|c|c|c|c}
\hline & GA3 & IAA & ZR & ABA & IAA/ABA & GA3/ABA & ZR/ABA & GA3/IAA ZR/IAA & ZR/GA3 \\
\hline LL & 0.65 & 0.02 & $-0.97^{*}$ & $1.00^{* *}$ & 0.01 & 0.86 & $-0.95^{*}$ & 0.37 & -0.63 & -0.74 \\
LW & -0.34 & 0.33 & $0.99^{* *}$ & -0.9 & 0.34 & $-0.98^{*}$ & $1.00^{* *}$ & -0.67 & 0.32 & 0.93 \\
LI & 0.31 & -0.36 & $-0.99^{*}$ & 0.88 & -0.37 & $0.99^{* *}$ & $-1.00^{* *}$ & 0.7 & -0.28 & -0.94 \\
LA & -0.09 & 0.56 & 0.93 & -0.75 & 0.57 & $-1.00^{* *}$ & $0.95^{*}$ & -0.84 & 0.06 & $0.99^{* *}$ \\
LC & -0.34 & 0.33 & $0.99^{* *}$ & -0.9 & 0.34 & $-0.99^{*}$ & $1.00^{* *}$ & -0.68 & 0.31 & 0.93 \\
LT & -0.21 & 0.46 & $0.97^{*}$ & -0.83 & 0.47 & $-1.00^{* *}$ & $0.98^{*}$ & -0.77 & 0.18 & $0.97^{*}$ \\
PL & -0.2 & 0.46 & $0.97^{*}$ & -0.82 & 0.47 & $-1.00^{* *}$ & $0.98^{*}$ & -0.77 & 0.18 & $0.97^{*}$ \\
UECL & -0.47 & 0.19 & $1.00^{* *}$ & $-0.95^{*}$ & 0.2 & -0.95 & $1.00^{* *}$ & -0.56 & 0.45 & 0.87 \\
UECW & $0.97^{*}$ & 0.6 & -0.65 & 0.86 & 0.6 & 0.4 & -0.59 & -0.24 & $-0.97^{*}$ & -0.21 \\
UECN & 0.17 & 0.76 & 0.8 & -0.56 & 0.76 & -0.94 & 0.84 & $-0.95^{*}$ & -0.2 & $0.99^{*}$ \\
LECL & $-0.99^{*}$ & -0.67 & 0.57 & -0.81 & -0.67 & -0.31 & 0.52 & 0.33 & $0.99^{*}$ & 0.12 \\
LECW & 0.18 & 0.76 & 0.8 & -0.55 & 0.77 & -0.94 & 0.84 & $-0.96^{*}$ & -0.21 & $0.99^{*}$ \\
LECN & 0.18 & 0.76 & 0.8 & -0.55 & 0.77 & -0.94 & 0.84 & $-0.96^{*}$ & -0.21 & $0.99^{*}$ \\
PN & 0.03 & 0.17 & 0.5 & 0.07 & -0.03 & -0.12 & 0.11 & -0.2 & 0.09 & 0.14 \\
PTT & -0.35 & 0.32 & $0.99^{* *}$ & -0.9 & 0.33 & $-0.98^{*}$ & $1.00^{* *}$ & -0.67 & 0.33 & 0.93 \\
PTCW & 0.06 & 0.68 & 0.86 & -0.65 & 0.69 & $-0.97^{*}$ & 0.9 & -0.91 & -0.09 & $1.00^{* *}$ \\
PTCL & 0.74 & $1.00^{* *}$ & 0.27 & 0.07 & $1.00^{* *}$ & -0.53 & 0.33 & -0.94 & -0.76 & 0.69 \\
STT & -0.18 & -0.76 & -0.8 & 0.55 & -0.77 & 0.94 & -0.84 & $0.95^{*}$ & 0.2 & $-0.99^{*}$ \\
PSR & -0.15 & 0.51 & $0.95^{*}$ & -0.79 & 0.52 & $-1.00^{* *}$ & $0.97^{*}$ & -0.81 & 0.13 & $0.98^{*}$ \\
\hline
\end{tabular}

$* \mathrm{p}<0.05, * * \mathrm{p}<0.01$

The content and ratio of endogenous hormones in leaves were taken as independent variables, and the leaf morphology was taken as dependent variable for stepwise regression analysis. The results showed that there was an extremely significant linear relationship between dependent variable $\mathrm{Y}$ and independent variable $\mathrm{X}$ (Table S3).

The results showed that the increase of ZR content had positive effects on leaf length, leaf circumference, leaf thickness, upper epidermal cell length, palisade tissue thickness and palisade tissue/spongy tissue ratio. The increase of ZR/ABA and ZR/GA 3 ratio had a positive effect on petiole length. The increase of $\mathrm{GA}_{3} / \mathrm{IAA}$ ratio had a positive effect on the lower epidermal cell width, indicating that ZR content, ZR/ABA, $\mathrm{ZR} / \mathrm{GA}_{3}$ and $\mathrm{GA}_{3} / \mathrm{IAA}$ ratio played an important role in the enhancement of xerophytic structure in heteromorphic leaves. 


\section{Relationship between leaf carbohydrate content and morphological structure of heteromorphic leaves}

Correlation analysis showed (Table 3) that the soluble sugar and soluble protein content in heteromorphic leaves significantly or extremely significantly positively correlated with Leaf width, leaf area, leaf circumference, leaf thickness, petiole length, length of upper and lower epidermal cells, number of upper and lower epidermal cells, lower epidermal cell width, palisade tissue thickness, palisade tissue cell width and palisade tissue/spongy tissue ratio. There was a significant or extremely significant negative correlation between leaf index and spongy tissue thickness, while the starch content showed the opposite, namely an extremely significant positive correlation with Leaf length, indicating that the change of leaf morphology and structure was closely related to the significant increase of leaf soluble sugar and soluble protein and the significant decrease of starch content.

Table 3. The morphological and structural parameters of heteromorphic leaves correlated with the carbohydrate content of leaves by Pearson

\begin{tabular}{c|c|c|c}
\hline & Soluble sugar & Starch & Soluble protein \\
\hline LL & -0.63 & $0.90^{* *}$ & -0.53 \\
LW & $0.69^{*}$ & $-0.95^{* *}$ & $0.67^{*}$ \\
LI & $-0.78^{* *}$ & $0.99^{* *}$ & $-0.76^{*}$ \\
LA & $0.74^{*}$ & $-0.93^{* *}$ & $0.81^{* *}$ \\
LC & $0.71^{*}$ & $-0.94^{* *}$ & $0.72^{*}$ \\
LT & $0.79^{* *}$ & $-0.96^{* *}$ & $0.80^{* *}$ \\
PL & $0.80^{* *}$ & $-0.87^{* *}$ & $0.82^{* *}$ \\
UECL & $0.78^{* *}$ & $-0.85^{* *}$ & $0.71^{*}$ \\
UECW & -0.14 & 0.23 & -0.08 \\
UECN & $0.93^{* *}$ & $-0.86^{* *}$ & $0.94^{* *}$ \\
LECL & 0.08 & -0.09 & -0.02 \\
LECW & $0.93^{* *}$ & $-0.88^{* *}$ & $0.96^{* *}$ \\
LECN & $0.93^{* *}$ & $-0.88^{* *}$ & $0.96^{* *}$ \\
PN & $0.69^{*}$ & 0.6 & $0.94^{* *}$ \\
PTT & $0.80^{* *}$ & $-0.85^{* *}$ & $0.68^{*}$ \\
PTCW & $0.76^{*}$ & $-0.88^{* *}$ & $0.83^{* *}$ \\
PTCL & 0.14 & -0.11 & 0.14 \\
STT & $-0.94^{* *}$ & $0.65^{*}$ & $-0.88^{* *}$ \\
PSR & $0.92^{* *}$ & $-0.83^{* *}$ & $0.82^{* *}$ \\
\hline
\end{tabular}

$* \mathrm{p}<0.05, * * \mathrm{p}<0.01$

Stepwise regression analysis was conducted with leaf carbohydrate as the independent variable and leaf morphology as the dependent variable, and the results showed that there was an extremely significant linear relationship between the dependent variable $\mathrm{Y}$ and the independent variable $\mathrm{X}$ (Table S4).

The results showed that the increase of soluble sugar content had positive effects on petiole length, leaf width, leaf area, petiole length, leaf thickness, upper epidermal cell length, upper epidermal cell number, palisade tissue thickness and spongy tissue thickness. The increase of soluble protein content had a positive effect on leaf index and palisade tissue/spongy tissue ratio. The increase of starch content had a positive effect on the lower epidermal cell width and palisade tissue thickness, indicating that the increase of carbohydrate content played an important role in the enhancement of xerophytic structure of heteromorphic leaves. 


\section{Discussion}

\section{The relationship between the morphological structure of heteromorphic leaves and the developmental stage and canopy height of P. pruinosa}

To adapt to dry conditions, plants in desert areas try their best to change their morphological characteristics, such as stomatal depression and leaf thickening, so as to resist the adverse effects of drought stress on plants (Mendes et al., 2001). Thicker leaves can maintain a higher water content, and at the same time avoid the burning of mesophyll caused by intense light in arid areas. In addition, scattered light can be effectively used for photosynthesis, which is conducive to the improvement of timeconcordant efficiency of leaves under water stress (Chartzoulakis et al., 2002; Velikova et al., 2020), therefore, trees adapt to the environment by adjusting their leaf morphology and biochemical characteristics (Kenzo et al., 2006). However, with the increase of ontogenetic stage and tree height, the demand for nutrients and water will continue to increase, and at the same time, a stronger ability to adapt to the environment such as drought resistance is required. On one hand, it is possible to increase the photosynthetically available area of leaves by increasing leaf area, leaf perimeter and leaf thickness, and further improve photosynthesis (Oikawa et al., 2016; Wang et al., 2017). On the other hand, increasing petiole length, palisade tissue thickness and palisade to sea ratio of leaves can effectively reduce leaf temperature, reduce transpiration, and water loss, and maintain high water content (Bridge et al., 2013; Velikova et al., 2020). Studies have shown that with the increase of ontogenetic stage and tree height, leaf thickness, epidermal cell number, palisade tissue cell number, palisade tissue thickness and palisade tissue/spongy tissue ratio of heteromorphic leaves increase, and their drought resistance is gradually enhanced (Zhang et al., 2017; Zhai et al., 2019, 2020).

In this study, the morphological and structural differences of $P$. pruinosa heteromorphic leaves during ontogeny reflect the synergistic or trade-off strategy between different traits and functions of leaves during ontogeny (Pan et al., 2018). Studies have found that the morphological and structural differences of $P$. pruinosa heteromorphic leaves are closely related to the increase of developmental stage and canopy height. From sapling to mature leaves, leaf thickness, leaf area, leaf quality and other traits showed significant changes with the DBH of trees (Martin et al., 2013), which was consistent with our research results. In addition, studies showed that the xerophytic structural characteristics of heteromorphic leaves became more and more obvious with the increase of development stage and canopy height, such as the enlargement of leaf area, the thickening of leaves, the increasingly developed palisade tissue, and the degeneration of spongy tissue in the cross section of leaves (Figure 1 and Figure S1,2). England and Attiwill (2006) found that the leaf shape of eucalyptus changed significantly with the increase of tree age and height, for example, the leaf length became shorter, the leaf thickness increased, and the leaf area index and specific leaf area decreased. Some studies showed that the palisade tissue thickness, palisade to sea ratio and epidermal thickness of leaves increased with the increase of tree height. The more obvious xerophytic structure is adapted to the water stress caused by arid environment and the increase of tree height (He et al., 2008; Zhai et al., 2020), water stress may eventually limit leaf expansion and photosynthesis to further increase tree height (Koch et al., 2004), and at the same time, the trend of changes in leaf structural traits is often interpreted as an adaptive response to light availability (Lusk et al., 2008). 
Therefore, it is speculated that the obvious xerophytic structure of the heteromorphic leaves of $P$. pruinosa is a self-protection to adapt to the water stress caused by the growth stage and the increase of tree height and to avoid the intense light.

\section{Effect of carbohydrate on morphological structure of heteromorphic leaves of $P$. pruinose}

Many studies have shown that starch, soluble sugar, and soluble protein are closely related to plant growth and development (Kuang et al., 2017; Liu et al., 2017, 2020). Starch is a key factor in mediating plant responses to abiotic stresses such as drought, as it compensates for changes in carbon assimilation to maintain levels of soluble sugars (Thalmann and Santelia, 2017). Previous studies have shown that the growth of trees under drought stress depends on the relationship between soluble sugar and starch, and there is a negative correlation between starch concentration and growth, and a positive correlation between soluble sugar/starch ratio and growth (Liu et al., 2017). In this study, it was found that the contents of soluble sugar, soluble protein and starch in heteromorphic leaves were closely related to the stage of ontogeny and canopy height. Göttlicher et al. (2006) found that the starch content of leaves gradually increased from the lower canopy to the higher canopy. Some studies showed that the starch content of leaves significantly negatively correlated with the diameter at breast height ( $\mathrm{Li}$ et al., 2015). However, it showed an increasing trend with the increase of canopy height (Figure 3B), which was consistent with the results of our study. Some authors found that the higher photosynthetic capacity was related to the increase of leaf carbohydrates (Aspinwall et al., 2016). Kenzo et al. (2006) found that the photosynthetic capacity of dipterocarp species depends on the height of the tree, and the trees adapt to the light environment by changing their leaf morphology and biochemical characteristics. The results showed that the content of osmotic regulatory substances such as soluble sugar could improve the photosynthetic capacity of heteromorphic leaves with the increase of canopy height.

Leaves mainly reduce osmotic potential and maintain turgor pressure through soluble osmotic regulatory substances, so that physiological processes related to turgor in plants can proceed normally (Patakas et al., 2002). In some studies, it has been found that the down-regulation of photosynthesis will offset the accumulation of starch in leaves in the long term (Quentin et al., 2013; Hagedorn et al., 2016). Soluble sugar produced by photosynthesis in leaves is exported from source leaves to phloem and is directly used for leaf growth (Lemoine et al., 2013). Some studies have found that soluble protein can be used as the main nitrogen source for leaf growth (Gonçalves et al., 2016; Liu et al., 2018). We found that the increase of soluble sugar and soluble protein and the decrease of starch content played an important role in enhancing the xerophytic structure of heteromorphic leaves. Drought stress results in the degradation of starch reserves in plant leaves into soluble sugars (Svensk et al., 2020), which can be used directly in physiological activities, including maintaining leaf turgor to resist drought (Martínez-Villata et al., 2016). Woodruff et al. (2011) found that leaf cell turgor pressure decreased with the increase of height. Therefore, with the increase of canopy height, leaves need to maintain turgor pressure by increasing the content of soluble substances to further drive leaf cell growth (Woodruff et al., 2015). Therefore, it can adapt to water stress caused by tree height and improve drought resistance ability. It was preliminarily speculated that the increase of soluble sugar and soluble protein and the 
decrease of starch content might regulate the enhancement of drought resistance ability in heteromorphic leaves of $P$. pruinose.

\section{Effects of endogenous hormone content and ratio on morphological structure of heteromorphic leaves of $P$. pruinose}

Plant hormones play an important role in regulating plant growth and development and coping with stress environment. Plant hormones, especially gibberellin $\left(\mathrm{GA}_{3}\right)$, auxin (IAA), abscisic acid (ABA) and corn nucleosides (ZR), can affect the formation and development of profiled leaves in many plants (Nakayama et al., 2017; Li et al., 2019). ZR can promote the cell division of stems and leaves, which is beneficial to the formation of leaves (Debnath, 2009). ABA controls the growth and development of plants, such as leaf shedding, fruit ripening and drought stress response (Nakayama et al., 2017). Studies on various plants show that osmotic stress induces ABA production, and ABA plays a controlling role in the stress response and tolerance of plants (Yamaguchi-Shinozaki and Shinozaki, 2006; Nakashima and Yamaguchi-Shinozaki, 2013), and ABA accumulation in leaves helps to improve drought resistance (He et al., 2020). Some studies have found that IAA affects leaf morphology and development (Barkoulas et al., 2008; Koenig et al., 2009). In this study, it was found that the changes of $\mathrm{ZR}$ content and $\mathrm{ZR} / \mathrm{ABA}$ ratio in leaves were closely related to the increase of $\mathrm{DBH}$, and the ZR content in leaves basically increased with the increase of diameter class, but there was no significant difference among crown levels (Figure 2D). Li et al. (2017) found that the contents of $\mathrm{ZR}$ and $\mathrm{ABA}$ in leaves showed an overall trend of increase with the increase of tree age (diameter class). Our study showed that ZR content and $\mathrm{ZR} / \mathrm{ABA}$ ratio significantly or extremely significantly positively correlated with leaf width, leaf circumference, leaf area, leaf thickness, petiole length, upper epidermal cell length, palisade tissue thickness and gate to sea ratio. It was preliminarily speculated that ZR content and ZR/ABA ratio of heteromorphic leaves of $P$. pruinose were involved in the regulation of leaf morphology and structure changes with the increase of diameter step.

When plants suffer from adversity stress, they can balance the growth regulation substances by changing the way of synthesis, conduction, and metabolism of endogenous hormones to improve the stress resistance of plants. In this study, it was found that $\mathrm{ZR}$ content, $\mathrm{ZR} / \mathrm{ABA}, \mathrm{ZR} / \mathrm{GA}_{3}$, and $\mathrm{GA}_{3} / \mathrm{IAA}$ ratios played an important role in the structure enhancement of heteromorphic leaves. Some studies have shown that the number of upper and lower epidermal cells, the width of upper epidermal cells, the length of palisade tissue and the ratio of gate to sea of leaves reflect the drought resistance of plants (Chartzoulakis et al., 2002; Zhang et al., 2017), our study showed that leaf ZR content had significant positive effects on leaf length decrease, leaf circumference increase, leaf thickness increase, upper epidermal cell length increase, palisade tissue thickness increase and gate sea ratio increase, and ZR/ABA and ZR/GA 3 ratios had significant positive effects on petiole length increase. In addition, GA 3 /IAA ratio had a significant positive effect on the decrease of lower epidermal cell width. It was suggested that the increase of $\mathrm{ZR}$ content, the ratio of $\mathrm{ZR} / \mathrm{ABA}$ and $\mathrm{ZR} / \mathrm{GA}_{3}$ and the decrease of $\mathrm{GA}_{3} / \mathrm{IAA}$ might play an important regulatory role in improving the drought resistance in heteromorphic leaves of $P$. pruinose. 


\section{Conclusion}

This study shows that $P$. pruinose in different developmental stages and different shaped leaf canopy height in different forms, and the xerophytic structure of heteromorphic leaves increased obviously with the developmental stage and canopy height. The increase of soluble sugar and soluble protein content and the decrease of starch content may enhance the xerophytic structure of heteromorphic leaves by improving photosynthetic capacity and osmotic regulation ability. In addition, the increase of $\mathrm{ZR}$ content, $\mathrm{ZR} / \mathrm{ABA}, \mathrm{ZR} / \mathrm{GA}_{3}$ ratio and the decrease of $\mathrm{GA}_{3} / \mathrm{IAA}$ ratio may play an important regulatory role in the enhancement of xerophilous structure of heteromorphic leaves. The results indicated that the formation of heteromorphic leaves was regulated by the synergistic changes of leaf morphology, structure and physiological characteristics during the individual growth and development of $P$. pruinose and could better adapt to the water stress caused by tree height, which provide a theoretical basis for further research on the molecular mechanism of how leaf morphological structure and physiological characteristics resist extreme environments through coordinated changes.

Acknowledgements. This work was financially supported by the National Natural Sciences Foundation of China (31860198, 31460042, 31060026), Innovative team Building Plan for key areas of Xinjiang Production and Construction Corps (2018CB003).

\section{REFERENCES}

[1] Aspinwall, M. J., Drake, J. E., Campany, C., Vårhammar, A., Ghannoum, O., Tissue, D. T., Reich, P. B., Tjoelker, M. G. (2016): Convergent acclimation of leaf photosynthesis and respiration to prevailing ambient temperatures under current and warmer climates in Eucalyptus tereticornis. - New Phytol 212(2): 354-367.

[2] Bai, S. N. (2003): Plant development biology. - Peking University Press, Beijing, pp. 7273.

[3] Barkoulas, M., Hay, A., Kougioumoutzi, E., Tsiantis, M. (2008): A developmental framework for dissected leaf formation in the Arabidopsisrelative Cardamine hirsuta. Nature genetics 40(9): 1136-1141.

[4] Ben-Gera, H., Shwartz, I., Shao, M. R., Shani, E., Estelle, M., Ori, N. (2012): ENTIRE and GOBLET promote leaflet development in tomato by modulating auxin response. Plant J. 70(6): 903-915.

[5] Bridge, L. J., Franklin, K. A., Homer, M. E. (2013): Impact of plant shoot architecture on leaf cooling: a coupled heat and mass transfer model. - J R Soc Interface. 10(85): 20130326.

[6] Burgess, S. S. O., Dawson, T. E. (2007): Predicting the limits to tree height using statistical regressions of leaf traits. - New Phytol. 174(3): 626-636.

[7] Cai, Y. L., Song, Y. C. (2001): Adaptive ecology of lianas in Tiantongevergreen broadleaved forest, Zhejiang, China- I. Leaf anatomical characters. - Acta Phytoecol. Sin. 25: 90-98.

[8] Chartzoulakis, K., Loupassaki, M., Bertaki, M., Androulakis, I. (2002): Effects of NaCl salinity on growth, ion content and $\mathrm{CO}_{2}$ assimilation rate of six olive cultivars. - Scientia Horticulturae 96: 235-247.

[9] Debnath, S. C. (2009): A two-step procedure for adventitious shoot regeneration on excised leaves of lowbush blueberry. - Vitro Cellular \& Developmental Biology Plant 45(2): 122-128. 
[10] Duan, B., Li, Y., Zhang, X., Helena, K., Li, C. (2009): Water deficit affects mesophyll limitation of leaves more strongly in sun than in shade in two contrasting Picea asperata populations. - Tree Physiology 29(12): 1551-1561.

[11] England, J. R., Attiwill, P. (2006): Changes in leaf morphology and anatomy with tree age and height in the broadleaved evergreen species, Eucalyptus regnans F. Muell. Trees 20: 79-90.

[12] Gao, J. F. (2006): Experimental Guide of Plant Physiology. - China Higher Education Press, Beijing, pp. 122-125.

[13] Gonçalves, A. Z., Mercier, H., Oliveira, R. S., Romero, G. Q. (2016): Trade-off between soluble protein production and nutritional storage in Bromeliaceae. - Ann Bot. 118(6): 1199-1208.

[14] Göttlicher, S., Knohl, A., Wanek, W., Buchmann, N., Richter, A. (2006): Short-term changes in carbon isotope composition of soluble carbohydrates and starch: from canopy leaves to the root system. - Rapid Commun Mass Spectrom 20(4): 653-60.

[15] Hagedorn, F., Joseph, J., Peter, M., Luster, J., Pritsch, K., Geppert, U., Kerner, R., Molinier, V., Egli, S., Schaub, M., Liu, J. F., Li, M., Sever, K., Weiler, M., Siegwolf, R. T., Gessler, A., Arend M. (2016): Recovery of trees from drought depends on belowground sink control. - Nature Plants 2: 16111.

[16] He, C. X., Li, J. Y., Zhou, P., Guo, M., Zheng, Q. S. (2008): Changes of leaf morphological, anatomical structure and carbon isotope ratio with the height of the Wangtian tree (Parashorea chinensis) in Xishuangbanna, China. - J Integr Plant Biol. 50(2): 168-73.

[17] He, X., Xu, L., Pan, C., Gong, C., Wang, Y., Liu, X., Yu, Y. (2020): Drought resistance of Camellia oleifera under drought stress: Changes in physiology and growth characteristics. - PLoS One 15(7): e0235795.

[18] Kenzo, T., Ichie, T., Watanabe, Y., Yoneda, R., Ninomiya, I., Koike, T. (2006): Changes in photosynthesis and leaf characteristics with tree height in five dipterocarp species in a tropical rain forest. - Tree Physiol. 26(7): 865-873.

[19] Kenzo, T., Inoue, Y., Yoshimura, M., Yamashita, M., Tanaka-Oda, A., Ichie, T. (2015): Height-related changes in leaf photosynthetic traits in diverse Bornean tropical rain forest trees. - Oecologia 177(1): 191-202.

[20] Koch, G. W., Sillett, S. C., Jennings, G. M. (2004): Davis SD. The limits to tree height. Nature 428(6985): 851-854.

[21] Koenig, D., Bayer, E., Kang, J., Kuhlemeier, C., Sinha, N. (2009): Auxin patterns Solanum lycopersicum leaf morphogenesis. - Development 136: 2997-3006.

[22] Kuang, Y., Xu, Y., Zhang, L., Hou, E., Shen, W. (2017): Dominant Trees in a Subtropical Forest Respond to Drought Mainly via Adjusting Tissue Soluble Sugar and Proline Content. - Frontiers in plant science 8: 802.

[23] Kuwabara, A., Nagata, T. (2002): Views on developmental plasticity of plants through heterophylly. - Recent Res Dev Plant Physiol. 3: 45-59.

[24] Lemoine, R., La Camera, S., Atanassova, R., Dédaldéchamp, F., Allario, T., Pourtau, N., Bonnemain, J. L., Laloi, M., Coutos-Thévenot, P., Maurousset, L., Faucher, M., Girousse, C., Lemonnier, P., Parrilla, J. (2013): Durand, M. Source-to-sink transport of sugar and regulation by environmental factors. - Frontiers in Plant Science 4: 272.

[25] Li, J. H., Feng, M., Li, Z. J. (2015): Carbohydrate, Soluble Protein and Morphometric Changes of Leaves of Populus euphratica Oliv. Individuals under Different Developmental Stages. - Bulletin of Botanical Research 35(4): 521-527.

[26] Li, Y. L., Zhang, X., Feng, M., Han, Z. J., Li, Z. J. (2017): Characteristics of Endhormones in Leaf Blade of Populus euphratica Heteromorphic Leaves. - Journal of Tarim University 29(3): 7-13.

[27] Li, X., He, D., Guo, Y. (2019): Morphological structure and physiological research of heterophylly in Potamogeton octandrus. - Plant Systematics and Evolution 305: 223-232. 
[28] Li, G., Hu, S., Hou, H., Kimura, S. (2019): Heterophylly: Phenotypic Plasticity of Leaf Shape in Aquatic and Amphibious Plants. - Plants (Basel) 8(10): 420.

[29] Li, Z. J. (2020): Physiological and Molecular Mechanisms of Drought Resistance of Populus euphratica and Populus pruinosa. - China Science Press, Beijing, pp. 11-15.

[30] Li, G. J., Hu, S. Q., Yang, J. J., Hou, H. W. (2020): Advances of heterophylly studies in plant. - Plant Physiology Journal 56(10): 2067-2078.

[31] Liu, S. F., Jiao, P. P., Li, Z. J. (2016): Diversifolious Types and Spatiotemporal Characteristics of Populus pruinosa Schrenk. - Arid Zone Research 33(5): 1098-1103.

[32] Liu, J. F., Arend, M., Yang, W. J., Schaub, M., Ni, Y. Y., Gessler, A., Jiang, Z. P., Rigling, A., Li, M. H. (2017): Effects of drought on leaf carbon source and growth of European beech are modulated by soil type. - Sci Rep. 7: 42462.

[33] Liu, T., Ren, T., White, P. J., Cong, R., Lu, J. (2018): Storage nitrogen co-ordinates leaf expansion and photosynthetic capacity in winter oilseed rape. - J Exp Bot. 69(12): 29953007.

[34] Liu, Q., Huang, Z., Wang, Z., Chen, Y., Wen, Z., Liu, B., Tigabu, M. (2020): Responses of leaf morphology, NSCs contents and C:N:P stoichiometry of Cunninghamia lanceolata and Schima superba to shading. - BMC plant biology 20(1): 354.

[35] Lusk, C. H., Reich, P. B., Montgomery, R. A., Ackerly, D. D., Cavender-Bares, J. (2008): Why are evergreen leaves so contrary about shade? - Trends Ecol Evol. 23(6): 299-303.

[36] Martin, A. R., Thomas, S. C. (2013): Size-dependent changes in leaf and wood chemical traits in two Caribbean rainforest trees. - Tree Physiol 33(12): 1338-1353.

[37] Martínez-Vilalta, J., Sala, A., Asensio, D., Galiano, L., Hoch, G., Palacio, S., Piper, F., Lloret, F. (2016): Dynamics of non-structural carbohydrates in terrestrial plants: a global synthesis. - Ecological Monographs 86: 495-516.

[38] Mendes, M. M., Gazarini, L. C., Rodrigues, M. L. (2001): Acclimation of Myrtus communis to contrasting Mediterranean light environments - Effects on structure and chemical composition of foliage and plant water relations. - Environmental \& Experimental Botany 45(2): 165-178.

[39] Mommer, L., Visser, E. J. W. (2005): Underwater photosynthesis in flooded terrestrial plants: a matter of leaf plasticity. - Annals of Botany 96: 581-589.

[40] Nakashima, K., Yamaguchi-Shinozaki, K. (2013): ABA signaling in stress-response and seed development. - Plant Cell Rep. 32: 959-970.

[41] Nakayama, H., Nakayama, N., Seiki, S., Kojima, M., Sakakibara, H., Sinha, N., Kimura, S. (2014): Regulation of the KNOX-GA Gene Module Induces Heterophyllic Alteration in North American Lake Cress. - Plant Cell 26(12): 4733-4748.

[42] Nakayama, H., Sinha, N., Kimura, S. (2017): How Do Plants and Phytohormones Accomplish Heterophylly, Leaf Phenotypic Plasticity, in Response to Environmental Cues. - Frontiers in Plant Science 8: 1717.

[43] Oikawa, S., Ainsworth, E. A. (2016): Changes in leaf area, nitrogen content and canopy photosynthesis in soybean exposed to an ozone concentration gradient. - Environ Pollut. 215: 347-355.

[44] Pan, Y. P., Chen, Y. P., Wang, H. J., Ren, Z. G. (2018): Leaf Structure and Functional Traits of Populus euphratica. - Journal of Desert Research 38(4): 765-771.

[45] Patakas, A., Nikolaou, N., Zioziou, E., Radoglou, K., Noitsakis, B. (2002): The role of organic solute and ion accumulation in osmotic adjustment in drought-stressed grapevines. - Plant Science 163: 361-367.

[46] Purdy, S. J., Maddison, A. L., Cunniff, J., Donnison, I., Clifton-Brown, J. (2015): Nonstructural carbohydrate profiles and ratios between soluble sugars and starch serve as indicators of productivity for a bioenergy grass. - AoB Plants. 7: 32.

[47] Quentin, A. G., Close, D. C., Hennen, L. M., Pinkard, E. A. (2013): Down-regulation of photosynthesis following girdling, but contrasting effects on fruit set and retention, in two sweet cherry cultivars. - Plant Physiol Biochem 73: 359-367. 
[48] Selbig, J., Fernie, A. R., Altmann, T., Stitt, M. (2009): Starch as a major integrator in the regulation of plant growth. - Proc Natl Acad Sci USA 106(25): 10348-10353.

[49] Svensk, M., Coste, S., Gérard, B., Gril, E., Julien, F., Maillard, P., Stahl, C., Leroy, C. (2020): Drought effects on resource partition and conservation among leaf ontogenetic stages in epiphytic tank bromeliads. - Physiol Plant 170(4): 488-507.

[50] Thalmann, M., Santelia, D. (2017): Starch as a determinant of plant fitness under abiotic stress. - New Phytol 214(3): 943-951.

[51] Velikova, V., Arena, C., Izzo, L. G., Tsonev, T., Koleva, D., Tattini, M., Roeva, O., De, M. A., Loreto, F. (2020): Functional and Structural Leaf Plasticity Determine Photosynthetic Performances during Drought Stress and Recovery in Two Platanus orientalis Populations from Contrasting Habitats. - Int J Mol Sci. 21(11): 3912.

[52] Wang, H. Z., Han, L., Xu, Y. L., Niu, J. L., Yu, J. (2017): Effects of soil water gradient on photosynthetic characteristics and stress resistance of Populus pruinosa in the Tarim Basin, China. - Acta Ecologica Sinica 37(2): 432-442.

[53] Wanke, D. (2011): The ABA-mediated switch between submersed and emersed lifestyles in aquatic macrophytes. - J Plant Res 124(4): 467-475.

[54] Wei, Q. J. (1990): Populus euphratica Oliv. - China Forestry Publishing House, Beijing, pp. 1-99.

[55] Wells, C. L., Pigliucci, M. (2000): Adaptive phenotypic plasticity: the case of heterophylly in aquatic plants. - Perspectives in Plant Ecology Evolution and Systematics 3(1): $0-18$

[56] Winn, A. A. (1999): The functional significance and fitness consequences of heterophylly. - International Journal of Plant Sciences 160: 113-121.

[57] Woodruff, D. R., Meinzer, F. C. (2011): Water stress, shoot growth and storage of nonstructural carbohydrates along a tree height gradient in a tall conifer. - Plant Cell Environ 34(11): 1920-30.

[58] Woodruff, D. R., Meinzer, F. C., Marias, D. E., Sevanto, S., Jenkins, M. W., McDowell, N. G. (2015): Linking nonstructural carbohydrate dynamics to gas exchange and leaf hydraulic behavior in Pinus edulis and Juniperus monosperma. - New Phytol. 206(1): 411-421.

[59] Yamaguchi-Shinozaki, K., Shinozaki, K. (2006): Transcriptional regulatory networks in cellular responses and tolerance to dehydration and cold stresses. - Annu Rev Plant Biol. 57: 781-803.

[60] Zhai, J. T., Han, X. L., Li, Z. J. (2019): Evaluation of Drought Resistance of Different Development Stages of Populus pruinosa Based on the Leaf Anatomical Structure. Journal of Tarim University 31(4): 12-21.

[61] Zhai, J. T., Li, Y. L., Han, Z. J., Li, Z. J. (2020): Morphological, structural and physiological differences in heteromorphic leaves of Euphrates poplar during development stages and at crown scales. - Plant Biol. 22(3): 366-375.

[62] Zhang, J., Jiang, D., Liu, B., Luo, W., Lu, J., Ma, T., Wan, D. (2014): Transcriptome dynamics of a desert poplar (Populus pruinosa) in response to continuous salinity stress. - Plant Cell Reports 33(9): 1565-1579.

[63] Zhang, J. L., Li, Y. L., Pang, M. L., Zhu, C. G., Bi, Z. L. (2017): Comparison of Resistance of Anatomical Structure in the Heterophylly Mechanism of Sabina vulgaris. Acta Bot. Boreal.-Occident. Sin. 37(9): 1756-1763. 
A

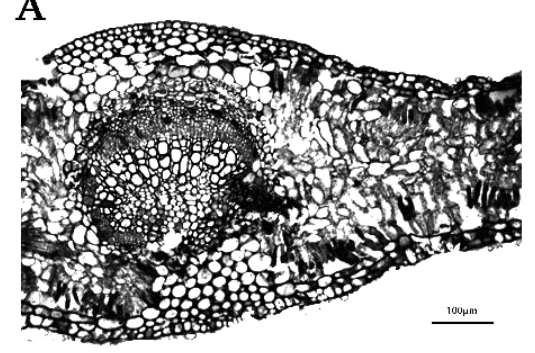

B
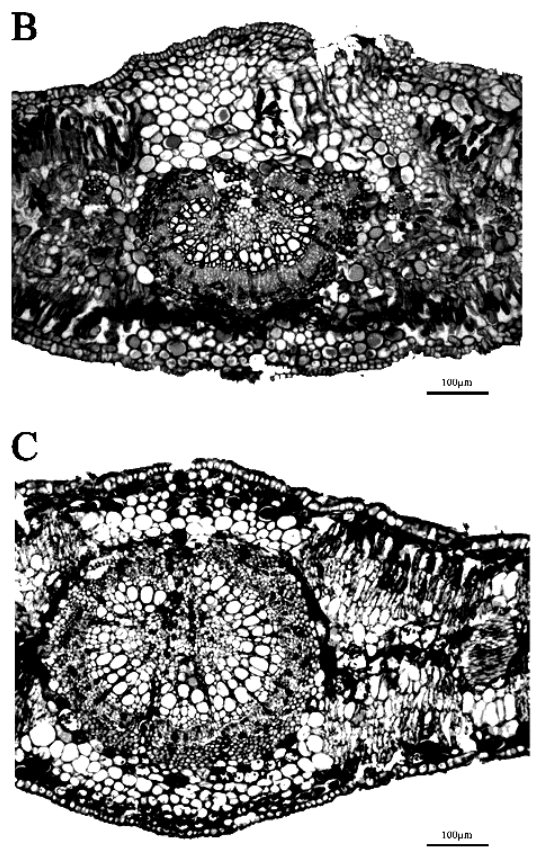

$\mathrm{D}$
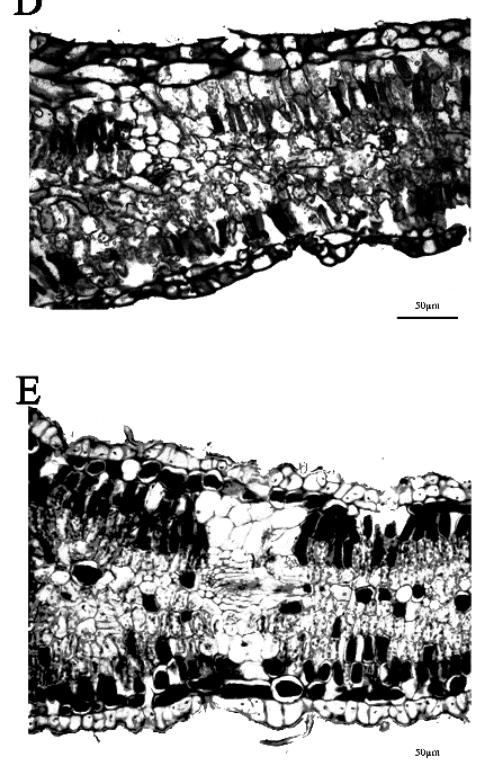

$\mathbf{F}$

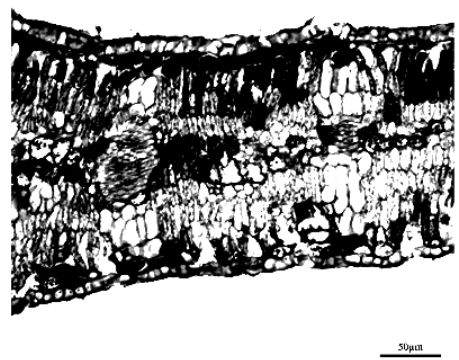

I
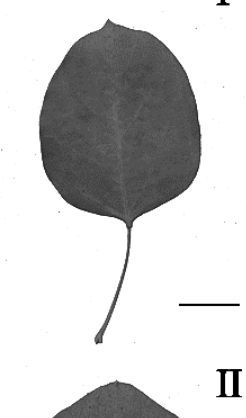

II

III

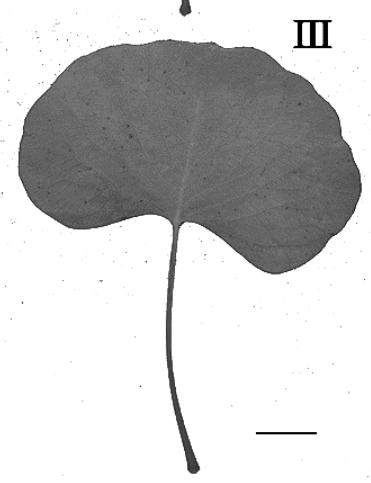

Plate I. Anatomic structure of long elliptic, round and broadly ovate leaves of P. pruinosa

(From top to bottom corresponding to the long elliptic ( I), circular (II), broad ovate (III) anatomical structure; A-C represents A $10 X 10$ times field of view, and D-F represents A $20 X 20$ times field of view 


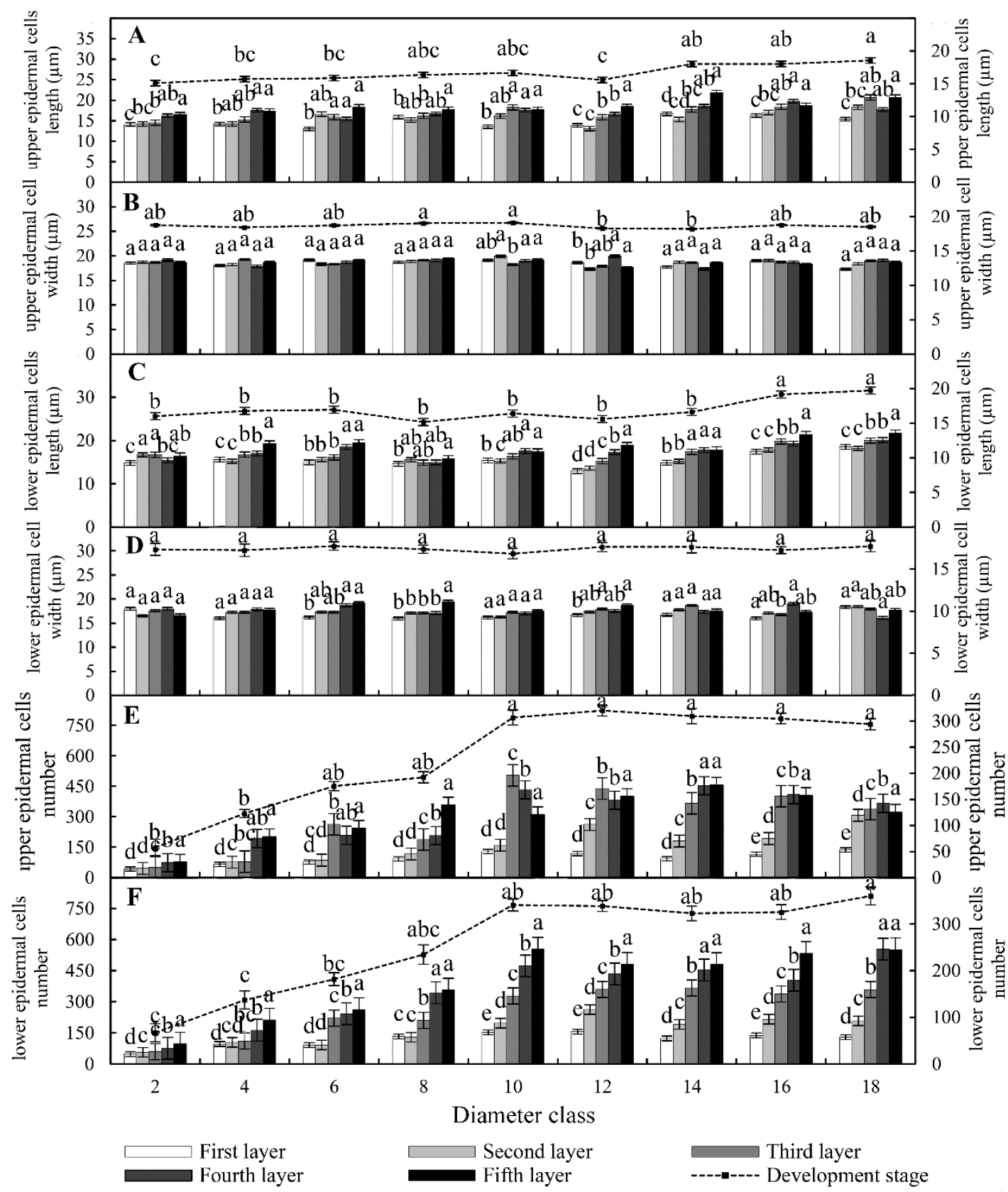

Figure S1. Changes of leaf epidermis with developmental stages and canopy height in cross section of heteromorphic leaves of $P$. pruinose. (A) length of upper epidermal cells, $(B)$ width of upper epidermal cells, $(C)$ length of lower epidermal cells, $(D)$ width of upper epidermal cells,

$(E)$ number of upper epidermal cells, and $(F)$ number of lower epidermal cells. Lowercase letters indicated significant differences, the same letters indicated not significant $(P>0.05)$, and different letters indicated significant differences $(P<0.05)$ 


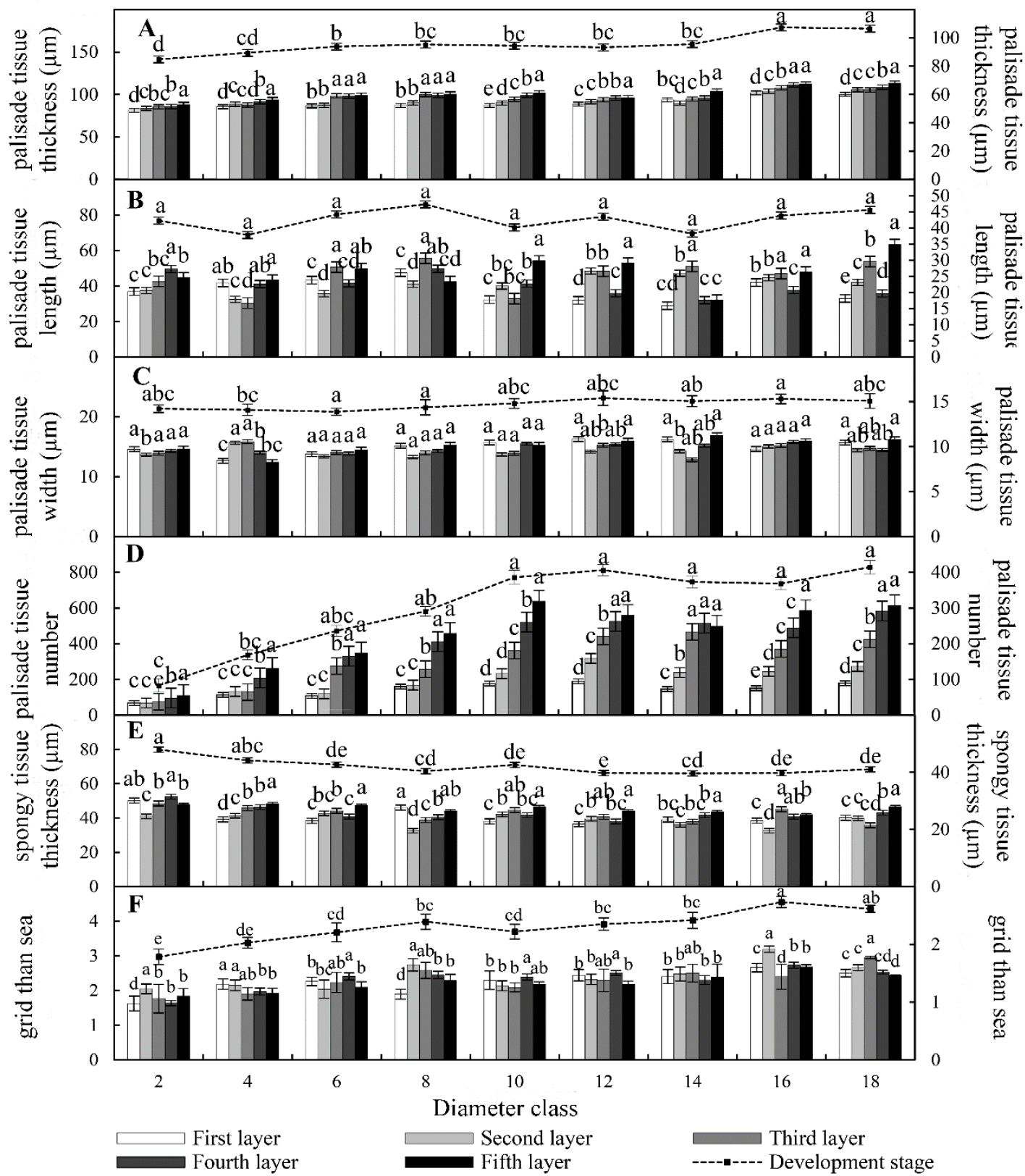

Figure S2. Changes of mesophyll tissue in cross section of heteromorphic leaves of P. pruinose with developmental stages and canopy height. (A) tissue thickness of fence, (B) tissue length of fence, $(C)$ tissue width of fence, $(D)$ tissue number of fence, $(E)$ tissue thickness of sponge fence,

$(F)$ ratio of fence to sea. Lowercase letters indicated significant differences, the same letters indicated not significant $(P>0.05)$, and different letters indicated significant differences $(P<0.05)$ 


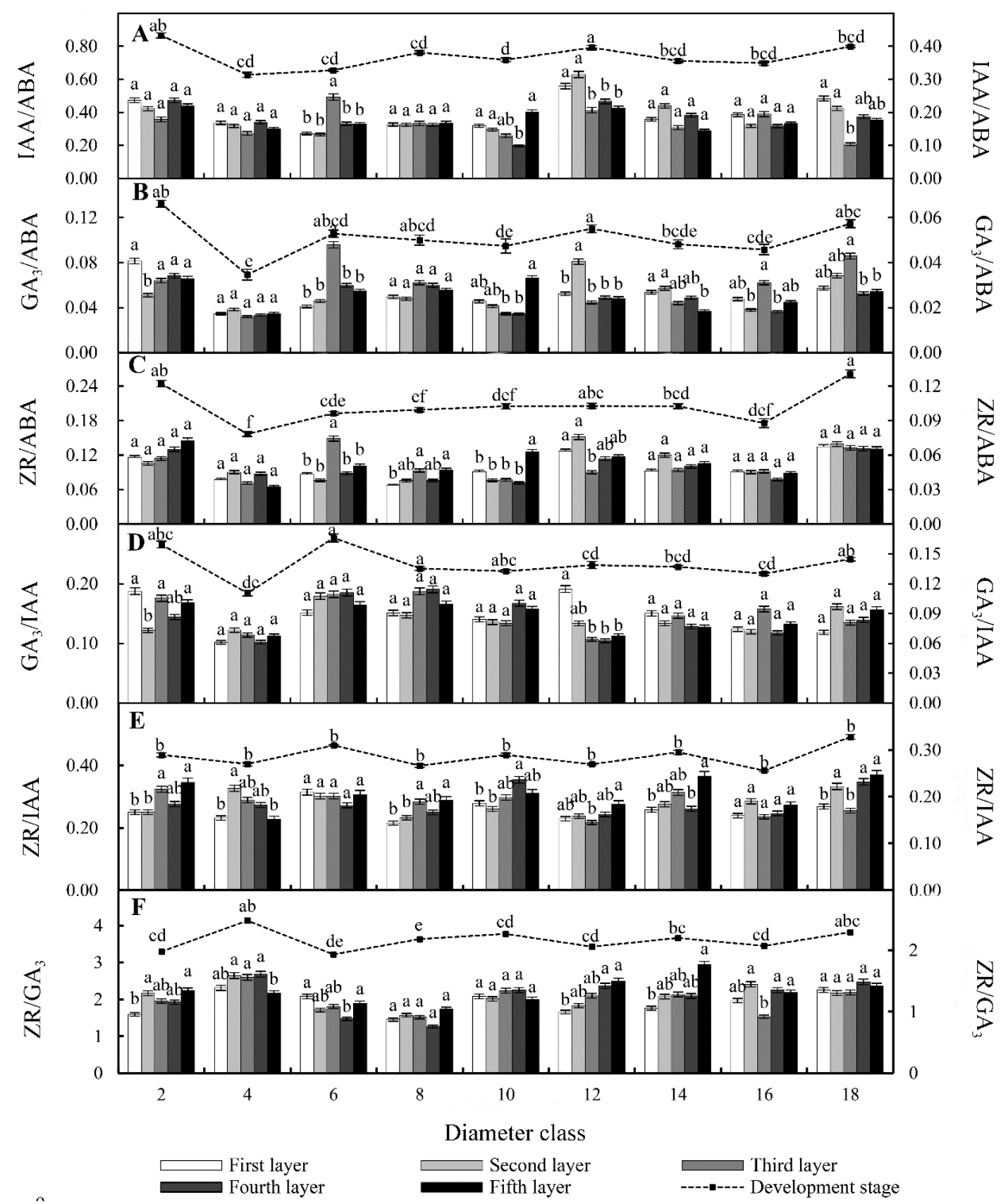

Figure S3. Changes of endogenous hormone ratio in heteromorphic leaves of P. pruinose with individual crown height and various developmental stages. (A)IAA/ABA, (B)GA $3 / A B A$,

$(C) Z R / A B A,(D) G A_{3} / I A A,(E) Z R / I A A,(F) Z R / G A_{3}$. Lowercase letters indicated significant differences, the same letters indicated not significant $(P>0.05)$, and different letters indicated significant differences $(P<0.05)$ 
Table S1. The morphological and structural changes of heteromorphic leaves were related to the Pearson of DBH and crown height of P. pruinosa

\begin{tabular}{|c|c|c|c|c|c|c|c|c|c|c|c|c|c|c|c|c|c|c|c|}
\hline & PL & $\mathbf{L L}$ & $\mathbf{L W}$ & LI & LA & LC & BT & UECL & UECW & LECL & LECW & UECN & LECN & $\mathbf{P N}$ & PTT & PTCL & PTCW & STT & PSR \\
\hline DBH & $0.89^{* *}$ & 0.38 & 0.54 & 0.37 & 0.53 & $0.67^{*}$ & 0.54 & $0.89^{* *}$ & -0.22 & $0.64^{*}$ & 0.21 & $0.91^{* * *}$ & $0.92^{* *}$ & $0.91^{* *}$ & $0.89^{* *}$ & 0.22 & $0.85^{* *}$ & $-0.79^{* *}$ & $0.92^{* *}$ \\
\hline $\mathbf{C H}$ & $0.83^{* *}$ & 0.34 & 0.48 & 0.43 & 0.48 & 0.6 & 0.49 & $0.81^{* *}$ & -0.22 & 0.5 & 0.15 & $0.97^{* *}$ & $0.97^{* *}$ & $0.96^{* *}$ & $0.81^{* *}$ & 0.16 & $0.89^{* *}$ & $-0.84^{* *}$ & $0.89^{* *}$ \\
\hline
\end{tabular}

Table S2. Four endogenous hormones and their ratios and carbohydrate of heteromorphic leaves were related to the Pearson of DBH and crown height of P. pruinosa

\begin{tabular}{c|c|c|c|c|c|c|c|c|c|c|c|c|c|c|}
\hline & GA3 & IAA & ZR & ABA & IAA/ABA & GA $_{3} / \mathbf{A B A}$ & ZR/ABA & GA $/$ IAA & ZR/IAA & SS & S & SP \\
\hline DBH & -0.18 & 0.48 & $0.96^{*}$ & -0.81 & 0.49 & $-1.00^{* *}$ & $0.98^{*}$ & -0.79 & 0.15 & $0.90^{* *}$ & $-0.97^{* *}$ & $0.86^{* *}$ \\
\hline CH & -0.02 & 0.62 & 0.9 & -0.71 & 0.63 & $-0.99^{*}$ & 0.93 & -0.88 & -0.01 & $0.94^{* *}$ & $-0.94^{* *}$ & $0.94^{* *}$ \\
\hline
\end{tabular}


Table S3. Optimal regression model for predicting the content and ratio of endogenous hormones and leaf morphology of P. pruinosa

\begin{tabular}{c|c|c|c|c|c}
\hline Dependent variable(Y) & Regression equation & $\mathbf{R}$ & $\mathbf{R}^{\mathbf{2}}$ & $\mathbf{F}$ & Sig. \\
\hline $\mathbf{Y}_{\mathbf{1}}$ & $\mathrm{Y}_{1}=1.60+0.12 \mathrm{X}_{1}+10.53 \mathrm{X}_{3}$ & 0.52 & 0.27 & 1.08 & 0.00 \\
$\mathbf{Y}_{\mathbf{2}}$ & $\mathrm{Y}_{2}=0.10-0.00026 \mathrm{X}_{3}$ & 0.85 & 0.72 & 18.31 & 0.00 \\
$\mathbf{Y}_{3}$ & $\mathrm{Y}_{3}=2.14+0.63 \mathrm{X}_{1}$ & 0.54 & 0.29 & 2.89 & 0.00 \\
$\mathbf{Y}_{\mathbf{4}}$ & $\mathrm{Y}_{4}=-47.64+17.14 \mathrm{X}_{1}$ & 0.52 & 0.27 & 2.54 & 0.00 \\
$\mathbf{Y}_{\mathbf{5}}$ & $\mathrm{Y}_{5}=5.88-83.70 \mathrm{X}_{2}+36.50 \mathrm{X}_{3}-1.72 \mathrm{X}_{5}$ & 0.77 & 0.59 & 2.43 & 0.00 \\
$\mathbf{Y}_{\mathbf{6}}$ & $\mathrm{Y}_{6}=4.63+0.75 \mathrm{X}_{1}$ & 0.45 & 0.20 & 1.80 & 0.00 \\
$\mathbf{Y}_{7}$ & $\mathrm{Y}_{7}=16.16+8.84 \mathrm{X}_{4}$ & 0.49 & 0.24 & 2.21 & 0.00 \\
$\mathbf{Y}_{\mathbf{8}}$ & $\mathrm{Y}_{8}=-20.13+7.17 \mathrm{X}_{1}$ & 0.74 & 0.55 & 8.58 & 0.00 \\
$\mathbf{Y}_{9}$ & $\mathrm{Y}_{9}=-1.85+0.26 \mathrm{X}_{1}$ & 0.68 & 0.46 & 5.99 & 0.00 \\
\hline
\end{tabular}

$\mathrm{Y}_{1}$, leaf length; $\mathrm{Y}_{2}$, leaf width; $\mathrm{Y}_{3}$, leaf circumference; $\mathrm{Y}_{4}$, leaf thickness; $\mathrm{Y}_{5}$, petiole length; $\mathrm{Y}_{6}$, length of upper epidermal cells; $\mathrm{Y}_{7}$, width of lower epidermal cells; $\mathrm{Y}_{8}$, thickness of palisade tissue; $\mathrm{Y}_{9}$, ratio of grid to sea; $\mathrm{X}_{1}, \mathrm{ZR} ; \mathrm{X}_{2}, \mathrm{GA}_{3} / \mathrm{ABA} ; \mathrm{X}_{3}, \mathrm{ZR} / \mathrm{ABA} ; \mathrm{X} 4, \mathrm{GA}_{3} / \mathrm{IAA} ; \mathrm{X} 5, \mathrm{ZR} / \mathrm{GA}_{3}$

Table S4. Optimal Regression Model for the Prediction of Carbohydrate and Leaf Morphological Structure of P. pruinosa Leaves

\begin{tabular}{c|c|c|c|c|c}
\hline Dependent variable(Y) & Regression equation & $\mathbf{R}$ & $\mathbf{R}^{\mathbf{2}}$ & $\mathbf{F}$ & Sig. \\
\hline $\mathbf{Y}_{\mathbf{1}}$ & $\mathrm{Y}_{1}=1.08+0.17 \mathrm{X}_{3}$ & 0.85 & 0.72 & 18.45 & 0.00 \\
$\mathbf{Y}_{\mathbf{2}}$ & $\mathrm{Y}_{2}=2.73+0.10 \mathrm{X}_{3}$ & 0.53 & 0.28 & 2.78 & 0.00 \\
$\mathbf{Y}_{\mathbf{3}}$ & $\mathrm{Y}_{3}=1.17+25.41 \mathrm{X}_{1}$ & 0.62 & 0.38 & 4.33 & 0.00 \\
$\mathbf{Y}_{\mathbf{4}}$ & $\mathrm{Y}_{4}=7.56+0.57 \mathrm{X}_{3}$ & 0.52 & 0.27 & 2.64 & 0.00 \\
$\mathbf{Y}_{\mathbf{5}}$ & $\mathrm{Y}_{5}=10.53+0.50 \mathrm{X}_{3}$ & 0.59 & 0.36 & 3.92 & 0.00 \\
$\mathbf{Y}_{\mathbf{6}}$ & $\mathrm{Y}_{6}=185.56+12.69 \mathrm{X}_{3}$ & 0.53 & 0.28 & 2.72 & 0.00 \\
$\mathbf{Y}_{\mathbf{7}}$ & $\mathrm{Y}_{7}=13.50+0.93 \mathrm{X}_{3}$ & 0.78 & 0.61 & 10.74 & 0.00 \\
$\mathbf{Y}_{\mathbf{8}}$ & $\mathrm{Y}_{8}=17.45+19.19 \mathrm{X}_{1}-7.62 \mathrm{X}_{2}$ & 0.54 & 0.29 & 1.24 & 0.00 \\
$\mathbf{Y}_{\mathbf{9}}$ & $\mathrm{Y}_{9}=-62.10+89.85 \mathrm{X}_{3}$ & 0.93 & 0.87 & 47.11 & 0.00 \\
$\mathbf{Y}_{\mathbf{1 0}}$ & $\mathrm{Y}_{10}=-64.13+94.11 \mathrm{X}_{3}$ & 0.93 & 0.87 & 46.93 & 0.00 \\
$\mathbf{Y}_{11}$ & $\mathrm{Y}_{11}=78.89-154.87 \mathrm{X}_{2}+7.25 \mathrm{X}_{3}$ & 0.89 & 0.81 & 12.42 & 0.00 \\
$\mathbf{Y}_{12}$ & $\mathbf{Y}_{12}=13.33+0.40 \mathrm{X}_{3}$ & 0.76 & 0.57 & 9.37 & 0.00 \\
$\mathbf{Y}_{13}$ & $\mathrm{Y}_{13}=50.37-2.46 \mathrm{X}_{3}$ & 0.94 & 0.89 & 57.96 & 0.00 \\
$\mathbf{Y}_{\mathbf{1 4}}$ & $\mathrm{Y}_{14}=1.51-4.44 \mathrm{X}_{2}+0.30 \mathrm{X}_{3}$ & 0.97 & 0.94 & 47.55 & 0.00 \\
\hline
\end{tabular}

$\mathrm{Y}_{1}$, long petiole; $\mathrm{Y}_{2}$, blade width; $\mathrm{Y}_{3}$, leaf shape index; $\mathrm{Y}_{4}$, leaf area; $\mathrm{Y}_{5}$, leaf circumference; $\mathrm{Y}_{6}$, leaf thickness; $Y_{7}$, length of upper epidermis; $Y_{8}$, width of lower epidermis; $Y_{9}$, number of upper epidermis; $\mathrm{Y}_{10}$, number of lower epidermis; $\mathrm{Y}_{11}$, thick fence tissue; $\mathrm{Y}_{12}$, wide fence organization; $\mathrm{Y}_{13}$, spongy tissue is thick; $Y_{14}$, ratio of grid to sea; $\mathrm{X}_{1}$, soluble protein content; $\mathrm{X}_{2}$, starch content; $\mathrm{X}_{3}$, soluble sugar content 